\section{Idowu Daniel Onisanwa}

(D) https://orcid.org/0000-0002-5751-9984

Economics and Development Studies, Humanities, Management and Social Sciences

Federal University, Kashere, Nigeria onidan@yahoo.com
Mercy Ojochegbe Adaji

iD https://orcid.org/0000-0002-0021-6827

CEPMLP

University of Dundee, Scotland, UK

msmercyadaji@gmail.com

\title{
Stock market development and investment growth in Nigeria
}

Accepted by Editor Ewa Ziemba | Received: March 19, 2020 | Revised: October 5, 2020; November 14, 2020; December 23, 2020; December 31, 2020 | Accepted December 31, 2020.

\begin{abstract}
Aim/purpose - The poor investment climate is one of the reasons advanced for the slow pace of growth in Nigeria; evidenced by the absence or inadequate amount of investible funds in the productive sectors. While the money market in Nigeria provides very limited investment options, the underdevelopment and underutilisation of the Nigerian Stock Market constitute a drawback to the investment climate. However, any economy desiring sustainable development requires a long-term source of fund. Therefore, this study ascertains the performance of the stock market and investment growth nexus in Nigeria.

Design/methodology/approach - The study is based on the neoclassical growth theory with a slight modification in the wake of Levine's specification (2003), an augmented investment growth relationship was specified. This study utilises the Autoregressive Distributed Lag (ARDL) in establishing the co-integration relation between stock market development and investment growth. Gross capital formation was used as a proxy for investment growth while the stock market indicators are market capitalisation ratio, total value traded ratio and turnover ratio. The study utilises data covering 1981 to 2018 , sourced from the Nigerian Stock Exchange annual reports and diverse publication of the Nigerian Bureau of Statistics.

Findings - The market capitalisation ratio had a negative impact on gross capital formation both in the short run and the long run, but its significance is only evident in the short run. The turnover ratio had a negative and significant impact on investment growth. The total value traded ratio exerted a positive and significant impact on gross capital formation both in the short run and the long run. The coefficient of the error correction term was negative and statistically significant.
\end{abstract}

Cited as: Onisanwa, I. D., \& Adaji, M. O. (2020). Stock market development and investment growth in Nigeria. Journal of Economics \& Management, 42(4), 99-117. https://doi.org/10.22367/ jem.2020.42.05 
Research implications/limitations - The total value traded ratio enhanced investment growth in Nigeria. Both market capitalisation and turnover ratio dampen investment growth. The Stock Exchange is not efficient and does not possess the amount of liquidity required to finance long term investment need in Nigeria. Emphasis on measures geared towards increasing efficiency and liquidity should be intensified by the government. Meanwhile, the sectorial analysis of the impact of stock exchange movements in Nigeria and the use of other estimation techniques may create room for more robust relationships.

Originality/value/contribution - The study directly investigates the capability of the Nigerian stock market in driving investment, both in the short and long run.

Keywords: Auto-Regressive Distributed Lag, investment growth, Nigeria, Stock Market. JEL Classification: G11, G140, O430.

\section{Introduction}

The economy of Nigeria is growing at a slow pace. Different reasons have been given for the slow growth in the economy, but the most likely cause has been the insufficient investment culture (Brown \& Nyeche, 2016; Thiele, Köster, Okoli, \& Rühmann, 2018). The poor investment climate, in turn, has been attributed to the absence or low level of investible funds, particularly in the productive sectors of the economy (Osamwonyi \& Kasimu, 2013). Furthermore, the Nigerian investment climate has been volatile, one of the reasons for the unsustainable growth of the economy.

However, for any economy aiming to attain sustainable development, a long-term source of fund is a necessary requirement (UNDP, 2013). This is simply because sustainable development requires the commitment of long-term adequate funding. There is no gainsaying that finance will play a crucial role in realizing these economic development and growth objectives. At different times, government and private investors have identified inadequate or lack of capital as one of the constraints to the implementation of economic development programmes and projects (Adenuga, 2010; Brown \& Nyeche, 2016; Salawu, 2007). Indeed, bridging the gap between the current situations and where we ought to be necessitates the application of a combination of strategies that include the creation of an enabling environment and adequate funding.

In the past, government administratively hold down the interest rate with the hope that funds would readily be available to entrepreneurs for financing projects (Nwachukwu \& Odigie, 2011). However, following the deregulation of interest rate and the consequent rise in the cost of funds, it has become imperative for entrepreneurs to go beyond the money market in order to meet their fi- 
nancial needs. The past and prevailing regimes of high and unstable interest rate have induced a process of deindustrialisation rather than promoting investment in manufacturing sector, agricultural sector, and other key sectors of the economy (Ifeakachukwu \& Ditimi, 2014; Svilokos, Vojinic, \& Suman Tolic, 2019). In these circumstances, a substantial proportion of the financial requirements for sustainable development must be met with the assistance of the stock market.

The stock market is an institution that helps mobilise and allocate capital efficiently for economic development (Afolabi, Olanike, Olusegun, \& Ibimilua, 2017). It serves as an avenue through which firms and governments raise huge funds for long-term project. Furthermore, through the secondary market, it ensures the availability of funds for innovation and modernisation of industries, and provides long-term investors with the opportunity to convert their financial holdings of assets to cash (Adewuyi \& Olowookere, 2011).

To increase the performance of the stock market, the Nigerian Stock Exchange witnessed an increase in listed stocks after the deregulation of interest rate which signifies an increase in the rate of market participation and, in turn, expectations of positive ripple effects on its performance (Hossain \& Kamal, 2010). However, considering the level of industrial development in the country, it is obvious that many industrial establishments have had problem of inadequate capital to support their activities. This may be due to the several problems such as absence of appropriate measures to strengthen and expand the market information asymmetry, poor regulations as well as the challenge of employing professionalism and maintaining ethical standards (Chete, Adeoti, Adeyinka, \& Ogundele, 2014; Rasak, Ake, \& Asamu, 2018). Against this background, an analysis of investment behaviour and activities of stock market in Nigeria is imperative.

Consequently, as a way of addressing the gap, this study examines the determinant of stock market development and the transmission of share and stock to investment use. This study, therefore, examines the relationship that exists, if any, between the stock market development and investment growth in Nigeria.

The rest of the study is structured as follows. Section 2 presents the relevant literature review. The methodology and data are housed in Section 3. Findings of the study are considered in Section 4. Finally, the last section contains the conclusion comprising the implications, the contribution and the limitations of the study. 


\section{Literature review}

Theoretical and empirical evidence abound on the growth impacts of the stock market on investment; however, the relationship has been shrouded in controversy. The traditional growth theories argued that stock market evolution does not have a meaningful influence on investment growth. Some studies argued that stock markets are not instrumental in the attainment of sustainable development. Levine \& Zervos (1999) see the stock market as 'mere burgeoning casino where more and more players bet' and thus, is unimportantly not linked to economic and investment growth. Moreover Levine ${ }^{1}$ (2003) argued that rather than accelerating, a very liquid market could hurt investment growth. According to Nazir, Nawaz, \& Gilani (2010), and Abbas, Pei, \& Rui (2016) stock market has no significant influence on the growth of investment in Pakistan and Tanzania, respectively.

Some studies argued that stock market is an institution that dampens growth of the economy, owing to its susceptibility to adverse consequence associated with market failure; which is reflected in the elastic nature of the markets in most developing countries. According to Ake \& Ognaligui (2010), the erratic feature of the stock market frustrates stakeholders' efforts in ensuring efficiency of the investment in companies, and that the stock market may not support economic growth due to the speculative power of the actors which tends to increase returns on investment.

While examining the association between the stock market development and growth of some advanced countries' economy, Boubakari \& Jin (2010) found that money market institutions have the capacity to propel more long-term growth in the economy relative to the stock market. That is, the stock market has a lesser significant impact on economic growth relative to the banking system. In Uganda, Maghanga \& Quisenberry (2015) concluded that the role of stock market in economic growth was exaggerated.

Along the same line, Asante, Agyapong, \& Adam (2011) investigated the association between the stock market and economic performance and concluded that the stock exchange has an insignificant influence on economic development and sometimes acts as a hindrance to growth. The study suggested that African countries should stop devoting their limited resources to the stock market development given the several challenges competing for the scarce resources, such as the high prevalence of diseases, widespread poverty, inadequate social services, and poor state of infrastructure. They argued further that even in the presence of

\footnotetext{
1 For more detailed information see Levine's paper (2003, pp. 3-4).
} 
abundant resources, the stock market possesses the ability to expose a fragile economy of most developing countries to the short-term stabilisation effects and speculative inflows of capital.

However, Qamruzzaman \& Jianguo (2018) suggested that stock market development spurs economic growth in Bangladesh, Chipaumire \& Ngirande (2014) found that stock market liquidity has a positive influence on the growth in South Africa, and in Nepal, the stock exchange was found to enhance the growth of the economy (Baral, 2019). Conversely, Chen, Lee, \& Wong (2006), and Adjasi $\&$ Yartey (2007) opined that, financial structure expands in line with the growth of the economy and the evolvement of the capital market is a component of the evolution.

Specifically for Nigeria, the findings are mixed. Osamwonyi \& Kasimu (2013) found no causal association between the stock market development and economic growth. The study concludes that stock markets are not effective in the allocation of scarce resources to the productive sector of the economy. Nwaolisa, Kasie, \& Egbunike (2013) found that the stock market has no important influence on the growth of the Nigerian economy.

Some studies reported negative effects on the economy of Nigeria. For instance, Oladapo \& Ayowole (2013) found that stock market efficiency negatively affects the achievement of the manufacturing sector in Nigeria. Furthermore, Nneji (2013) suggests that stock market efficiency dampens the productivity of the manufacturing sector of the economy. Osho (2014) revealed that market capitalisation and the total value of traded ratio negatively impact economic growth, but the total turnover ratio exerts a positive influence on gross domestic product. Tokunbo \& Lloyd (2003) suggest that stock market growth nexus exhibited negative correlation in Nigeria. Popoola, Ejemeyovwi, Alege, Adu, \& Onabote (2017) examined the relationship between the stock market and economic growth. The study established the existence of a long-term relationship and revealed that the all-share index as a measure of the stock market significantly reduced the growth of the economy. However, the use of ordinary least square technique implies that the results must be accepted and interpreted with caveat given that the series are not of the same order of integration.

On the contrary, Adenuga (2010) showed that the market capitalisation ratio, turnover ratio and the total value of shares traded ratio were significant and positively influence economic growth. Nurudeen (2009) found that rising market capitalisation increases economic growth. Adewuyi \& Olowookere (2011) found that the capital market makes an important contribution to the development of the Nigerian economy by creating an efficient and conducive environment for 
diversification of investment. Gani \& Ibrahim (2015) established the existence of long term relationship among measures of stock market performance and economic growth. The study concludes that the stock market promotes economic wellbeing in Nigeria and the growth in turns contributes to its development. Likwise, Ihendinihu \& Onwuchekwa (2012), Popoola et al. (2014), Brown $\&$ Nyeche (2016) established a positive relationship between the stock market performance and economic growth in Nigeria.

Meanwhile, some studies found a mixed influence depending on the indicator for the stock market development. According to Afolabi et al. (2017), capital flow, stock turnover ratio and market capitalisation showed a significant and positive relationship with the economic growth in Nigeria. This implies that the capital market development increases the ability of firms to raise capital, expand investment and contribute to economic growth. On the contrary, the all-share index and value of transactions display a negative relationship with economic growth. This tends to pose an adverse influence on the growth of the economy as investors are discouraged. However, this study applied the OLS econometric approach in the analysis, but the use of OLS technique in this context is not suitable given that the series is of mixed order of integration.

Ariwa, Ani, Onyele, \& Ekeleme (2017) examined the influence of changes in all-share index and ratio of market capitalisation to nominal GDP as a measure of stock market efficiency and liquidity on the Nigerian manufacturing sector. Their findings showed that stock market liquidity does not significantly impact the manufacturing sector while market capitalisation tended to influence the growth of the sector positively, hence, mixed findings. Similarly, Afees \& Kazeem (2010) suggest a bidirectional relationship between the turnover ratio and economic growth. The study further reveals improvement in market capitalisation results in economic growth while the total value traded ratio has no significant impact on economic growth. Additionally, Ikoku (2010) reported a bidirectional causality between stock market development and economic activities. As evidenced by the reviewed works of the literature, the correlation between growth in the Stock Market and investment is yet unresolved.

\section{Research methodology}

\subsection{The model}

This study is a hypothesis on the neoclassical growth model with a slight modification. This offers explanation for the source of investment growth in an 
economy. Following the specification of Levine (2003), an investment growth relationship is specified as:

$$
\log (G C F)=f(\log (M C), \log (T V T), \log (T R))
$$

Equation 1, states that the gross capital formation denoted as $G C F$ is a function of the market capitalisation ratio $(M C)$, total value traded ratio (TVT)) and turnover ratio (TR). Each of the series is expressed in its natural logarithm.

The gross capital formation was used as a proxy for investment growth while the stock market indicators used in this study are the market capitalisation ratio, total value traded ratio and turnover ratio. These indicators are measures of stock market size and liquidity. The stock market size and liquidity are assumed to determine the level of investment growth in an economy. The capital base of a stock market, that is, the total value of listed shares, determines its ability to mobilise and channel resources to more productive venture, thereby minimising risk (Afees \& Kazeem, 2010; Tokunbo \& Lloyd, 2003). The liquidity of the stock market is measured by total value traded ratio and turnover ratio.

These indicators measure the degree of trading relative to the size of the economy and the market as against the ease of buying and selling securities by market agents. The ratio of the total value traded on the Nigerian Stock Exchange defines the worth of equity transactions with respect to the size of the economy. Meanwhile, the worth of equity transactions relative to the equity market size is measured as the value of total shares traded on the stock market divided by market capitalisation. This study utilises the Autoregressive Distributed Lag (ARDL) bound test approach developed by Pesaran, Shin \& Smith (2001) in establishing the cointegration relation between the stock market development and investment growth. Equation 1 can be specified in econometric format as

$$
\log \left(G C F_{t}\right)=\gamma_{1} \log \left(M C_{t}\right)+\gamma_{2} \log \left(T V T_{t}\right)+\gamma_{3} \log \left(T R_{t}\right)+\varepsilon_{t}
$$

Equation 2 is a regression of the log of GCF in year, $t$ against the log of MC at time $\mathrm{t}, \log$ of TVT at time, $\mathrm{t}, \log$ of TR at period, $\mathrm{t}$, and a white noise error term. $\gamma_{1}, \gamma_{2}$, and $\gamma_{3}$ are the parameters to be estimated. The model is specified and estimated based on time series, this gives rise to error correction model, provided there is co-integration among the series. 


\subsubsection{Unit root tests}

The series (gross capital formation, market capitalisation, total value traded and turnover ratio) will be tested for stationarity using Phillip-Peron (PP) and Augmented Dickey-Fuller tests before testing for co-integration using the (ARDL) bound test approach. The null hypothesis of a unit root against the onesided alternative will be accepted if the ADF or PP statistic is greater than the critical value and concludes that the series is non-stationary; otherwise (that is, if it is less), the series is stationary. Therefore, the Univariate time series properties will be established.

\subsubsection{Co-integration test - ARDL-bounds testing approach}

The bound co-integration is appropriate where the series are of different order of integration (Pesaran et al., 2001). The ARDL approach is unique in the sense that it does not necessitate the series being examined to be of the same order of integration. Therefore, the approach is useful when the series under investigation are of different order, that is integrated of order zero $I(0)$, and order one $I(1)$, in which the regressand must be $I(1)$. The computed F-statistics figure is compared with upper and lower critical figures which are determined by Pesaran et al. (2001).

If conclusion of co-integration can be ascertained from the bounds test, then a unit root test is not required. If series are not co-integrated based on Bounds test, only the short run model will be estimated. However, the long run and short run models are to be estimated if co-integration is established.

The bounds test regression for the series in this study is theoretically specified as:

$$
\begin{aligned}
\Delta\left[\log \left(G C F_{t}\right)\right]= & \gamma_{1} \log \left(G C F_{t-1}\right)+\gamma_{2} \log \left(M C_{t-1}\right)+\gamma_{3} \log \left(T V T_{t-1}\right)+\gamma_{4} \log \left(T R_{t-1}\right) \\
& +\sum_{i=1}^{p} \lambda_{i} \Delta \log \left(G C F_{t-i}\right)+\sum_{j=0}^{p} \psi_{j} \Delta \log \left(M C_{t-j}\right)+\sum_{r=0}^{p} \theta_{r} \Delta \log \left(T V T_{t-r}\right) \\
& +\sum_{q=0}^{p} \phi_{q} \Delta \log \left(T R_{t-q}\right)+\mu_{t}
\end{aligned}
$$

The expected signs of the short run parameters are: $\gamma_{1}<0 ; \gamma_{2} \neq 0 ; \gamma_{3} \neq 0$ and $\gamma_{4} \neq 0$.

Furthermore, the expected signs of the short-run parameters are $\lambda_{i} \neq 0 ; \psi_{j} \neq 0 ; \theta_{r} \neq 0$ and $\phi_{q} \neq 0$. The parameters $\gamma_{1}$ to $\gamma_{4}$ explain the long-run 
multipliers of the model, while the short-run dynamics coefficients are explained by parameters $\lambda_{i}, \psi_{j}, \theta_{r}$, and $\phi_{q} . \mu_{t}$ is the stochastic error term, normally distributed with zero mean, and variance of one. $p$ is the optimal lag length.

Equation (3) can be re-parameterised in order to estimate an unrestricted error correction model (ECM). The ECM model is specified as:

$$
\begin{aligned}
\Delta \log \left(G C F_{t}\right)= & \sum_{i=1}^{p} \lambda_{i} \Delta \log \left(G C F_{t-i}\right)+\sum_{j=0}^{p} \psi_{j} \Delta \log \left(M C_{t-j}\right)+\sum_{r=0}^{p} \theta_{r} \Delta \log \left(T V T_{t-r}\right) \\
& +\sum_{q=0}^{p} \phi_{q} \Delta \log \left(T R_{t-q}\right)+\alpha E C M_{t-1}+\varepsilon_{t}
\end{aligned}
$$

Where $\Delta$ denotes first difference operator, $\alpha$ expresses the short run dynamics of the model's convergence to equilibrium after a shock, $\varepsilon_{t}$ is the disturbance term assuming white noise and normal distribution. The parameterised model is obtainable because the ARDL is a dynamic single system equation of the form of an ECM (Nkoro \& Uko, 2016).

The choice of the ARDL is based on its suitability for this study, in the sense that the ARDL approach assumes just one reduced form of equation association between GCF, and MC, TVT, as well as TR. The ARDL approach also has the ability to identify co-integrating vectors in a case of more than one co-integrating vectors. Meanwhile, through a simple linear transformation, the reparameterised ECM is obtained from the ARDL model (Nkoro \& Uko, 2016; Pesaran \& Shin, 1999).

The goodness of fit of the ARDL model was ascertained by following the general approach of Hendry (1995) in selecting a model that satisfies the relevant diagnostic tests: Breusch-Godfrey serial correlation LM test, ARCH test for heteroscedasticity, the Jarque-Bera normality test, and Ramsey RESET test for the linearity of the model. The structural stability test is conducted using the CUSUM test.

The statistical behaviour of the series is analysed, after which the order of integration of the variables was established using the ADF and PP statistics. The study then estimated the ARDL model employing the length of the optimal lags while considering the significance of the parameters and careful analyses of residuals. The optimal model was selected based on the outcomes of the diagnostic tests. The bounds test was performed to establish the long-run relationship among the series. The section concluded by estimating the elasticities of the model both in the short and long-run. 


\subsection{Data}

This study employs mainly secondary data sources to collect relevant information for the successful accomplishment of the set objective. The data sources include the Nigerian Stock Exchange Annual report (2018), and Central Bank of Nigeria annual report (2018). The study utilises data covering 1981 to 2018.

\section{Research findings/results}

\subsection{Descriptive statistics}

The result of the descriptive statistics of gross capital formation (GCF), market capitalisation (MC), and total value traded (TVT) and turnover ratio (TR) is presented in Table 1 .

Table 1. Descriptive statistics

\begin{tabular}{|l|r|r|r|r|}
\hline \multicolumn{1}{|c|}{ Specification } & \multicolumn{1}{c|}{ GCF } & MC & \multicolumn{1}{c|}{ TVT } & \multicolumn{1}{c|}{ TR } \\
\hline Mean & 37.11 & 14.58 & 1.19 & 7.16 \\
\hline Median & 36.63 & 10.89 & 0.61 & 6.82 \\
\hline Maximum & 89.38 & 51 & 8.65 & 29.40 \\
\hline Minimum & 14.90 & 3.84 & 0.02 & 0.43 \\
\hline Std. Dev. & 19.29 & 10.43 & 1.80 & 5.98 \\
\hline Skewness & 0.98 & 1.68 & 2.93 & 1.83 \\
\hline Kurtosis & 3.67 & 5.72 & 11.12 & 7.31 \\
\hline Jarque-Bera & 6.67 & 28.87 & 154.37 & 49.13 \\
\hline Probability & 0.04 & 0 & 0 & 0 \\
\hline Observations & 37 & 37 & 37 & 37 \\
\hline
\end{tabular}

Source: Authors' compilation.

\subsection{Unit root test results}

The optimal lag length is determined through the Schwarz Info Criterion (SIC). The unit root test results from Augmented Dickey-Fuller (ADF) and Phillip Peron (PP) across two-equation test options are presented in Table 2. The results revealed a mixed order of integration, as such the probable existence of a long-run relationship is investigated. 
Table 2. Summary of unit root test results

\begin{tabular}{|l|r|r|r|r|r|c|}
\hline \multirow{2}{*}{ Specification } & \multicolumn{2}{|c|}{ Augmented Dicke-Fuller (ADF) } & \multicolumn{3}{|c|}{ Phillip Perron (PP) } \\
\cline { 2 - 7 } & \multicolumn{1}{|c|}{ level } & first difference & $\mathrm{I}(\mathrm{d})$ & \multicolumn{1}{c|}{ level } & first difference & $\mathrm{I}(\mathrm{d})$ \\
\hline GCF & $-3.20^{* *(\mathrm{a})}$ & & $\mathrm{I}(0)$ & $-3.18^{* *(\mathrm{a})}$ & & $\mathrm{I}(0)$ \\
\hline MC & $-2.80^{*(\mathrm{a})}$ & & $\mathrm{I}(0)$ & $-2.90^{(\mathrm{a})}$ & & $\mathrm{I}(0)$ \\
\hline TVT & $-2.60^{(\mathrm{b})}$ & $-6.25^{* * *(\mathrm{a})}$ & $\mathrm{I}(1)$ & $-2.11^{(\mathrm{b})}$ & $-4.94^{* * *(\mathrm{a})}$ & $\mathrm{I}(1)$ \\
\hline TR & $-2.43^{(\mathrm{b})}$ & $-6.17^{* * *(\mathrm{a})}$ & $\mathrm{I}(1)$ & $-2.43^{(\mathrm{b})}$ & $-6.48^{* * *(\mathrm{a})}$ & $\mathrm{I}(1)$ \\
\hline
\end{tabular}

Note: Where I (d) denotes the order of integration; $\mathrm{a}=$ test equation with intercept; $\mathrm{b}=$ test equation with trend and intercept. $* * *, * *, *$ imply $1 \%, 5 \%$ and $10 \%$ level of significance, respectively.

Source: Authors' computation.

Table 3. ARDL Bounds Test

\begin{tabular}{|c|c|c|}
\hline Test Statistic & Value & K \\
\hline F-statistic & 6.94269 & 3 \\
\hline \multicolumn{3}{|c|}{ Critical Value Bounds } \\
\hline Significance & I (0) Bound & I (1) Bound \\
\hline $10 \%$ & 2.37 & 3.2 \\
\hline $5 \%$ & 2.79 & 3.67 \\
\hline $2.50 \%$ & 3.15 & 4.08 \\
\hline $1 \%$ & 3.65 & 4.66 \\
\hline
\end{tabular}

Source: Authors' computation.

$\mathrm{K}$ is the ARDL model maximum lag order chosen based on Schwartz Criterion (SC). If the computed $F$-statistic figure is greater than the upper critical figure, then the null hypothesis of no co-integration cannot be accepted and vice versa. The long-run relationship will be estimated with the best ARDL model based on Schwartz Criterion (SC). The ARDL model maximum lag order (K) was chosen based on the Schwartz Information Criterion (SIC).

\subsection{Presentation of results}

Given that the probable existence of a long run relationship between the variables has been ascertained, both the short and long run dynamics are presented. 
Table 4. ARDL regression results

\begin{tabular}{|c|c|c|c|}
\hline \multicolumn{2}{|c|}{ Long-run results } & \multicolumn{2}{c|}{ Short-run results } \\
\hline variable & coefficient & variable & coefficient \\
\hline MC & $-0.28(0.97)$ & $\Delta S M C$ & $-0.08(2.76)$ \\
\hline TVT & $9.18(3.02)$ & $\Delta T V T$ & $2.77(2.76)$ \\
\hline TR & $-3.84(-4.50)$ & $\Delta T R$ & $-0.53(3.53)$ \\
\hline \multicolumn{2}{|r|}{} & $E C M(-1)$ & $-0.30(6.33)$ \\
\hline
\end{tabular}

Source: Authors' computation.

Table 5. Results of the diagnostic test

\begin{tabular}{|l|c|}
\hline \multicolumn{1}{|c|}{ Test Statistics } & Probability \\
\hline Breusch-Godfrey test (Serial Correlation) & $(0.86)$ \\
\hline Heteroskedasticity (ARCH) & $(0.74)$ \\
\hline Linearity (Ramsey Reset) & $(0.20)$ \\
Normality (Jarque-Bera) & $(0.98)$ \\
\hline CUSUM Test & Stable \\
\hline
\end{tabular}

Source: Authors' computation using E-views 10.

\section{Discussion}

The result of the descriptive statistics of gross capital formation, market capitalisation, total value traded, and turnover ratio is presented in Table 1. The mean values for gross capital formation, market capitalisation, total value traded and turnover ratio are presented in Table 1 . The minimum values and maximum values are also reported. The table shows that given the acceptance/rejection criteria, the variables are not normally distributed since the probability values computed for Jacque-Bera Chi-square distribution are less than the conventional statistical significance levels, the null hypothesis that the series is normally distributed is rejected. That is, the series is not normally distributed. This result is further evidenced by the skewness and kurtosis statistics of the series. The standard deviation indicates that gross capital formation has the highest deviation from its mean among the series under consideration, while total value traded has the least variation from its mean.

The unit root test results from Augmented Dickey-Fuller (ADF) and Phillip Peron (PP) across two equation test options are presented in Table 2. The results revealed a mixed order of integration, as such the probable existence of a longrun relationship was investigated. 
TVT and TR are integrated of order one, while GCF and MC are stationary at level. Given that the series is of a different order of integration, the appropriate co-integration test is the Bounds test developed by Pesaran et al. (2001).

The ARDL Bounds test result (Table 3) shows that the F-statistic (6.94) obtained is greater than the upper bound I (1) at the conventional critical significance levels. Thus, we conclude that there is co-integration among the variables. That is, the long-run relationship between the explained and explanatory variables can be ascertained.

The empirical results revealed that market capitalisation ratio has a negative relationship with gross capital formation and the result is statistically insignificant in the long run. This shows that the stock market capitalisation only influences the level of investment in Nigeria in the short run. Turnover ratio, however, has a statistically significant and negative influence on the growth of investment. Meanwhile, the total value traded ratio has a positive and significant impact on gross capital formation growth in the long run. This implies an increase in total value traded has the ability to raise the level of investment, thereby increasing the level of economic activities vis-à-vis economic growth in the long run.

The results are in conformity with the outcomes of some studies. Ariwa et al. (2017) show that market capitalisation has a marginal influence on the growth of the economy. Nneji (2013) found the existence of a negative relationship between the capital market capitalisation and the growth of the economy in Nigeria. Similarly, Osho (2014) reported a positive but insignificant relationship between the total market capitalisation and the growth of the Nigerian economy. Their findings further showed that the total value of stock has a negative effect on the GDP growth rate, but not statically significant.

The study concluded that the stock market in Nigeria plays no important role in explaining growth in the long run. This study confirmed the argument that the stock market in most African countries is not fully endowed and lacks the necessary trading instruments to influence long term investment as well as economic growth. The negative and statistically insignificant relation can also be attributed to poor awareness among the people and the fact that many investors prefer investing their resources in other profitable sectors.

On the contrary, the results did not conform to the findings of several studies. The results of studies such as those of Afees \& Kazeem (2010) and Adewuyi \& Olowookere (2011) showed a positive and significant relationship between stock market and the level of economic growth in Nigeria. Afolabi et al. (2017) 
found a positive and significant relationship between the value traded ratio and gross capital formation and concluded that stock markets affect the amount of capital available for investment purposes.

The speed at which equilibrium is restored in the model is described by the short-run dynamics. It conveys information about the speed of adjustment via the coefficient of the error correction term ECM $(-1)$. The error correction term is negative and statistically significant as expected. This further affirms the existence of a long-run relationship among the series in the model, an indication of the speed at which the model reverses back to equilibrium after a disturbance. The coefficient of CointEq $(-1)$ is -0.30206 , that is, assuming other factors are held constant, about 30 per cent of last year's deviation from equilibrium owing to shock moves back to long-run equilibrium in the current period. All the co-efficients are statistically significant in explaining investment growth in the short-run, while the signs of the short run dynamic coefficients are identical to the long-run coefficients.

The validity of the long-run model was ascertained using Breusch-Godfrey serial correlation LM test, ARCH heteroscedasticity test, and the Ramsey RESET test, as well as Jarque-Bera statistics. The outcomes of the diagnostic tests affirmed that the long-run model is statistically valid over time. The model has the correct specification, there is neither serial correlation nor heteroscedasticity among the residuals as revealed by the non-significant probability statistics of the respective tests. Therefore, the model can be relied on for the formulation of economic policy and future forecasting on issues related to stock market and growth of investment in Nigeria.

\section{Conclusions}

\subsection{Research contribution}

This study examined the effect of stock market development on investment growth in Nigeria. It investigates the impact of stock market measures: market capitalisation ratio, total value traded ratio and turnover ratio on investment growth (gross capital formation) in Nigeria using Autoregressive Distributive Lag (ARDL) approach. Unlike other studies on the capital market development that dwell on the economic growth impacts of the stock market, this study examines directly, the capability of the stock market in driving the growth of investment in Nigeria, rather than inferring that the stock market promotes investment 
based on its economic growth nexus. It must be noted that there are other factors other than the stock market that contribute immensely to the growth of the economy.

\subsection{Research implication}

The results reveal that the stock market capitalisation ratio and turnover ratio exert a negative influence on the investment growth both in the short and long run, except in the case of the market capitalisation ratio that is not statically significant in the long run. The finding also reveals a positive and statistically significant influence of the total value traded ratio on investment growth, both in the short and long run. The results of this study tend to refute the hypothesis of stock market-led investment growth in the Nigerian situation, contrary to the findings of Afolabi et al. (2017). These findings mean that the Nigerian stock exchange is not efficient and does not possess the liquidity required to finance long term investment needs of the economy.

The results further suggest that the stock market development has not significantly influenced investment in Nigeria, although it has shown the capability to trigger investment growth. There is a need for policymakers to promote policy geared towards stock market development in order to guarantee capital mobilisation for long-term investment.

\subsection{Research limitation and future works}

Based on the empirical findings of this study, there are possibilities for future research on the imperative of stock market measures on investment growth in Nigeria. Given that our study could not account for the sectorial impact of stock market measures, there is a need for sectorial analysis of the impact of the stock exchange market in Nigeria. This will provide comprehensive information on the investment growth capability of the stock market. It is imperative to have a future empirical analysis of the stock market volatility, efficiency and forecasting for varying periods of reforms, policies and economic recessions. Furthermore, the evidence of the long-run relationship between measures of the stock market and gross capital formation may encourage the development of the theoretical framework of investment growth by incorporating the stock market in the Nigerian case. 


\section{References}

Abbas, A. O., Pei, Y. X., \& Rui, Z. (2016). Impact of stock market on economic growth evidence: Dar-es Salaam stock exchange - Tanzania. Journal of Finance and Accounting, 4(6), 321-327. https://doi.org/10.11648/j.jfa.20160406.12

Adenuga, A. O. (2010, March). Stock market development indicators and economic growth in Nigeria (1990-2009): Empirical investigations. Economic and Financial Review, 48(1), 33-70.

Adewuyi, I. D., \& Olowookere, J. K. (2011). The contributions of capital market to economic development in Nigeria. International Journal of Economic Development Research and Investment, 2(1), 36-46.

Adjasi, C. K., \& Yartey, C. A. (2007). Stock market development in Sub-Saharan Africa: Critical issues and challenges (No. 7-209). Washington, DC: International Monetary Fund.

Afees, A. S., \& Kazeem, B. A. (2010). The stock market and economic growth in Nigeria: An empirical investigation. Journal of Economics Theory, 4(2), 65-70. https://doi.org/10.3923/jeth.2010.65.70

Afolabi, B., Olanike, A. B., Olusegun, A. O., \& Ibimilua, S. T. (2017). Interconnection between capital market indices and economic growth: Nigeria's perspective (19892015). Advances in Social Sciences Research Journal, 4(18), 160-173. https:// doi.org/10.14738/assrj.418.2429

Ake, B., \& Ognaligui, R. (2010). Financial stock market and economic growth in developing countries: The case of Douala Stock Exchange in Cameroon. International Journal of Business and Management, 5(5), 82-88. https://doi.org/ $10.5539 / \mathrm{ijbm} . v 5 \mathrm{n} 5 \mathrm{p} 82$

Ariwa, F. O., Ani, O. I., Onyele, K. O., \& Ekeleme, I. J. (2017). Impact of stock market liquidity and efficiency on performance of the manufacturing sector in Nigeria. International Journal of Economics and Financial Management, 2(1), 71-82.

Asante, S., Agyapong, D., \& Adam, A. M. (2011). Bank competition, stock market and economic growth in Ghana. International Journal of Business Administration, 2(4), 33-41. https://doi.org/10.5430/ijba.v2n4p33

Baral, K. B. (2019). Effects of stock market development on economic growth in Nepal. Janapriya Journal of Interdisciplinary Studies, 8, 87-96. https://doi.org/10.3126/ jjis.v8i0.27302

Boubakari, A., \& Jin, D. (2010). The role of stock market development in economic growth: evidence from some Euronext countries. International Journal of Financial Research, 1(1), 14-20. https://doi.org/10.5430/ijfr.v1n1p14

Brown, E., \& Nyeche, E. (2016). The imperative of stock market on economic growth in Nigeria: "The Endogenous Growth Model”. Business and Economic Journal, 7(1), 1-5. https://doi.org/10.4172/2151-6219.1000200 
Central Bank of Nigeria. (2018). Annual report and statement of accounts. Abuja: Author. Retrieved March 10, 2020 from https:/www.cbn.gov.ng/documents/ cbnannualreports.asp

Chen, P.-F., Lee, Ch. Ch., \& Wong, S. Y. (2006, October). Is rate of stock returns a leading indicator of output growth? In the case of four East Asian countries. In 9th Joint International Conference on Information Sciences (JCIS-06). Amsterdam: Atlantis Press.

Chete, L. N., Adeoti, J. O., Adeyinka, F. M., \& Ogundele, O. (2014). Industrial development and growth in Nigeria: Lessons and challenges (Working Paper, No. 2014/019). Helsinki: UNU-WIDER.

Chipaumire, G., \& Ngirande, H. (2014). How stock market liquidity impact economic growth in South Africa. Journal of Economics, 5(2), 185-192. https://doi.org/ 10.1080/09765239.2014.11884995

Gani, I. M., \& Ibrahim, S. S. (2015). Capital market development and economic growth: Evidence from Nigeria. International Journal of Social Sciences and Humanities Research, 3(5), 22-32.

Hendry, D. F. (1995). Dynamic econometrics. Oxford: Oxford University Press on Demand.

Hossain, M. S., \& Kamal, K. M. (2010). Does stock market development cause economic growth? A time series analysis for Bangladesh economy. In L. Tsipouri, N. Tsounis, \& A. Vlachvei (Eds.), International conference on applied economics 2010 (pp. 289-297). Athens: TEI of Western Macedonia Press.

Ifeakachukwu, N. P., \& Ditimi, A. (2014). Capital inflows and exchange rate in Nigeria. Mediterranean Journal of Social Sciences, 5(7), 263-272. https://doi.org/10.5901/ mjss.2014.v5n7p263

Ihendinihu, J. U., \& Onwuchekwa, J. C. (2012). Stock market performance and economic growth in Nigeria (1984-2011). Journal of Emerging Trends in Economics and Management Sciences, 3(6), 971-977.

Ikoku, A. E. (2010). Is the stock market a leading indicator of economic activity in Nigeria? CBN Journal of Applied Statistics, 1(1), 17-38.

Levine, R. (2003). Stock market liquidity and economic growth: Theory and evidence. In L. Paganetto \& E. S. Phelps (Eds.), Finance, research, education and growth (pp. 3-24). London: Palgrave Macmillan.

Levine, R., \& Zervos, S. (1999). Stock market development and long-run growth. Washington, DC: The World Bank.

Maghanga, M., \& Quisenberry, W. (2015). The role of Uganda Securities Exchange in the economic growth of Uganda: An econometric analysis. International Journal of Econometrics and Financial Management, 3(3), 131-141. https://doi.org/10.12691/ ijefm-3-3-4 
Nazir, M. S., Nawaz, M. M., \& Gilani, U. J. (2010). Relationship between economic growth and stock market development. African Journal of Business Management, 4(16), 3473-3479. https://doi.org/10.5897/AJBM.9000484

Nkoro, E., \& Uko, A. K. (2016). Autoregressive Distributed Lag (ARDL) cointegration technique: Application and interpretation. Journal of Statistical and Econometric Methods, 5(4), 63-91.

Nneji, I. (2013). Efficiency of the Nigerian capital market; an empirical analysis. Research Journal of Finance and Accounting, 4(4), 69-77.

Nurudeen, A. (2009). Does stock market development raise economic growth? Evidence from Nigeria. The Review of Finance and Banking, 1(1), 15-26.

Nwachukwu, T. E., \& Odigie, P. (2011), What drives private saving in Nigeria (Paper Presented at Workshop Organized by AERC). Nairobi: African Economic Research Consortium (AERC).

Nwaolisa, E. F., Kasie, E. G., \& Egbunike, C. F. (2013). The impact of capital market on the growth of the Nigerian economy under democratic rule. Oman Chapter of Arabian Journal of Business and Management Review, 3(2), 53-62. https:// doi.org/10.12816/0002371

Oladapo, F., \& Ayowole, A. J. (2013). An empirical analysis of efficiency of the Nigerian capital market. Research Journal of Finance and Accounting, 4(17), 111-117.

Osamwonyi, I. O., \& Kasimu, A. (2013). Stock market and economic growth in Ghana, Kenya and Nigeria. International Journal of Financial Research, 4(1), 83-98. https://doi.org/10.5430/ijfr.v4n2p83

Osho, A. E. (2014). The role of stock market on Nigeria's economic development. International Journal of Scientific and Research Publications, 4(4), 424-430.

Pesaran, M. H., \& Shin, Y. (1999). An autoregressive distributed-lag modelling approach to cointegration analysis. Econometric Society Monographs, 31, 371-413.

Pesaran, M. H., Shin, Y., \& Smith, R. J. (2001). Bounds testing approaches to the analysis of level relationships. Journal of Applied Econometrics, 16(3), 289-326. https://doi.org/10.1002/jae.616

Popoola, O. R., Ejemeyovwi, O. J., Alege, O. P., Adu, O., \& Onabote, A. (2017). Stock market and economic growth in Nigeria. International Journal of English Literature and Social Sciences, 2(6), 97-106. https://doi.org/10.24001/ijels.2.6.15

Qamruzzaman, M., \& Jianguo, W. (2018). Financial innovation, stock market development, and economic growth: An application of ARDL model. International Journal of Financial Studies, 6(69), 1-30. https://doi.org/10.3390/ijfs6030069

Rasak, B., Ake, M., \& Asamu, F. (2018). Nigeria's industrial policies, sustainable development and the challenges of globalization. Abuja Journal of Sociological Studies, 5(1), 119-151.

Salawu, R. O. (2007). An empirical analysis of the capital structure of selected quoted companies in Nigeria. The International Journal of Applied Economics and Finance, 1(1), 16-28. https://doi.org/10.3923/ijaef.2007.16.28 
Svilokos, T., Vojinić, P., \& Šuman Tolić, M. (2019). The role of the financial sector in the process of industrialisation in Central and Eastern European countries. Economic Research-Ekonomska Istraživanja, 32(1), 384-402. https://doi.org/10.1080/ 1331677x.2018.1523739

The Nigerian Stock Exchange. (2018). Annual report. Lagos: Stock Exchange House. Retrieved March 10, 2020 from http://www.nse.com.ng/aboutussite/Annual\% 20Reports/The\%20Nigerian\%20Stock\%20Exchange\%202018\%20Annual\%20Rep ort.pdf

Thiele, R., Köster, M., Okoli, I., \& Rühmann, F. (2018). African economic development: What role can the G20 Compact play? (Discussion Paper, No. 3). Bonn: German Development Institute.

Tokunbo, S. O., \& Lloyd, A. A. (2003). Stock market development and long-run growth in Nigeria. Journal of African Business, 4(3), 103-129. https://doi.org/10.1300/ J156v04n03_06

UNDP. (2013). Raising resources to finance the post-2015 development agenda: Synthesis of the Johannesburg Roundtable of Expert. Pretoria, South Africa: Author. 